\title{
GGE Biplot Analysis for Stability and Adaptability of Maize Hybrids in Western Region of Indonesia
}

\author{
Dedi Ruswandi $\mathbb{D}^{1}{ }^{1}$ Muhammad Syafii $\left(\mathbb{D},{ }^{2}\right.$ Haris Maulana ${ }^{D},{ }^{1}$ Mira Ariyanti ${ }^{D},{ }^{1}$ \\ Nyimas Poppy Indriani, ${ }^{3}$ and Yuyun Yuwariah ${ }^{1}$ \\ ${ }^{1}$ Faculty of Agriculture, University of Padjadjaran, Jl. Raya Bandung-Sumedang, Jatinangor, Indonesia \\ ${ }^{2}$ Faculty of Agriculture, University of Singaperbangsa Karawang, Kabupaten Sumedang, Jawa Barat, Indonesia \\ ${ }^{3}$ Faculty of Animal Husbandry, University of Padjadjaran, Kabupaten Sumedang, Jawa Barat, Indonesia
}

Correspondence should be addressed to Dedi Ruswandi; d.ruswandi@unpad.ac.id

Received 25 May 2021; Accepted 21 July 2021; Published 31 July 2021

Academic Editor: Mehdi Rahimi

Copyright $(2021$ Dedi Ruswandi et al. This is an open access article distributed under the Creative Commons Attribution License, which permits unrestricted use, distribution, and reproduction in any medium, provided the original work is properly cited.

Hybrids that are stable or adaptable in a specific location for the western region of Indonesia are required to increase production of maize in Indonesia. The objectives of the study were (i) to select maize hybrids which are stable or adaptable in the western region of Indonesia and (ii) to determine the discriminant location for evaluating superior hybrids in the western region. Therefore, twelve maize hybrids were planted in different locations and seasons in the western region. Hybrids were selected based on GGE biplot analysis. The results showed that G9 and G10 were stable maize hybrids. G6 was the selected hybrid for the first megaenvironment; whereas, G3 was selected as the hybrid for the second megaenvironment. The L8 and L17 were the discriminant environment for evaluating hybrids in the western region of Indonesia. The high-yielding hybrids selected in this study should be broadly evaluated on-farm in order to disseminate for small holder farmers in Sumatera and Java islands.

\section{Introduction}

Maize is an important crop in Indonesia since this crop supplies human energy consumption and livestock feed as well. Indonesia is amongst the top ten maize producers in the world which is indicated by its domestic maize production at around twenty million tons for 2019. Maize farming in Indonesia is widely located in various geographic islands such Java and Sumatera islands for western region, Kalimantan and Nusa Tenggara islands for middle region and Sulawesi, Moluccas, and Papua islands for eastern region. In addition, the western region of Indonesia contributed more than $50 \%$ of national production of maize [1].

An effort to increase national maize production can be accomplished by planting maize hybrid varieties adapting in a particular location. The continued use of hybrid demands more superior maize hybrid varieties with a consistent performance. Therefore, efforts are needed to develop and to evaluate of new potential maize hybrid varieties across multiple environments.
Selection of yield is a difficult stage in developing maize hybrid since their performance is inconsistence due to the existence of genetic by environment interaction (GEI). Yield as an agronomy and economically significant trait is quantitatively polygenic in nature and demonstrate GEI [2]. Therefore, evaluation of yield for maize hybrids under the multiple environment trials (METs) is required [3]. Some researchers mentioned the importance of METs including (i) to estimate the significant of GEI, (ii) to identify the highest yielding cultivars by selecting specific adapted genotype in particular environment, (iii) to identify consistent-performing and high-yielding genotypes by selecting wide adapted genotype in broad environment, and (iv) to detect the best sites indicating the target environment [2-4].

Numerical parametric and nonparametric stabilities as well as graphical stability analysis have been used by many breeders to determine stability and adaptability of new varieties. Yan et al. [5] developed the genotype main effect $(G)$ plus the genotype $\times$ environment interaction (GE) to evaluate superior cultivar in graphical analysis for METs. 
Genotype and genotype $\times$ environment (GGE) has been widely used to study stability and adaptability in various plant commodities since this method provides three important aspects such as megaenvironment analysis, genotype evaluation, and test site for target environment [6]. Akinwale et al. [7] summarized the display of GGE biplot for the following: (i) the polygon view that shows the winning genotype in different environments, (ii) the average tester coordination that ranks genotype based on their performance and stability across environment, and (iii) the vector view which shows the discriminating ability and representativeness of environment. GGE biplot had been used to evaluate various crops such as durum [8], lentil [9], maize [10], maize as a silage [11], sorghum [12], sweet corn [13], and sweet potato [14]. The objectives of the research are (i) to select superior maize hybrids with the best stability and adaptability in the western region of Indonesia and (ii) to determine the discriminant location for evaluating superior hybrids in the western region of Indonesia.

\section{Materials and Methods}

2.1. Experimental Material and Treatments. The experiments were conducted in 11 locations during dry season 2013 and 10 locations during rainy season of 2014. The agroclimate of locations is presented in Table 1. The 11 locations were Karo in North Sumatera; Tanjung Bintang and Gunung Sugih in Lampung for Sumatera Island; Jatinangor in West Java; Karanganom in Klaten, Jogonalan in Klaten, and Boyolali in Central Java; Probolinggo, Jember, Nganjuk, and Kediri in East Java for Java Island. The 10 locations were Karo in North Sumatera, Gunung Sugih in Lampung for Sumatera Island; Jatinangor in West Java, Karanganom in Klaten, Jogonalan in Klaten, and Boyolali in Central Java; Probolinggo, Jember, Nganjuk, and Kediri in East Java for Java Island. The first planting was during dry season from August 2013 up to November 2013 and the second one from November 2013 up to February 2014. Eleven maize hybrids were used for the experiment. These hybrids were 4 commercial hybrids and 7 newly developed maize hybrids through the breeding program of the Plant Breeding and Seed Technology Laboratory, Padjadjaran University. The maize hybrid had high-yield potentials, enriched in nutrients such as starch and high protein (Table 2).

The experiment was laid in a randomized block design with three replications. Genetic materials were planted as four rows plot, $5 \mathrm{~m}$ long, $0.75 \mathrm{~m}$ between rows, and $0.25 \mathrm{~m}$ spacing in row. Character to be observed was yield (ton $\mathrm{ha}^{-1}$ ). Yield was measured following [15]. Cobs were separately harvested from two rows at maturity, and the fresh cob was weighted for every plot. Grains were shelled from ten randomly cobs to estimate the percent grain moisture and shelling \% at harvest for every plot. The shelling \% was calculated using the following formula: shelling percentage $(\mathrm{SP})=($ grain weight $/$ cob weight $\times 100)$

Yield $\left(\mathrm{t} \mathrm{ha} \mathrm{h}^{-1}\right.$ ) was estimated from fresh cob per plot using the following formula:

$$
\text { Yield }=\frac{y \times(100-\mathrm{MC}) \times \mathrm{SP} \times 10}{(100-15) \times 7.5},
$$

where $\mathrm{MC}$ is the moisture content in grains at harvest (\%); SP is the shelling percentage; area harvested plot $^{-1}$ is $7.5 \mathrm{~m}^{2}$; 1 hectare $=10,000 \mathrm{~m}^{2} ; 15 \%=$ moisture content required in maize grain at storage.

\section{Statistical Analysis}

Analysis of variance for yield was estimated following [16]. Homogeneity of variance errors for twenty-one location in the western region was counted by the Barlett test [16]. Combined ANOVA of all locations were performed to calculate the $G \times E$ interaction if variance errors were homogenous.

Superior maize hybrids were selected using GGE biplot analysis. The GGE (Genotype and Genotype × Environment) biplot was proposed by [5] to select high-yield varieties that are stable and adaptable to multienvironment conditions. The GGE biplot model was formulated as [17]: $Y_{h i j}=\mu+E_{h}+G_{i}+G E_{h i}+B_{j(h)}+e_{h i j}$, where $\mu$ is the population mean, $E_{h}$ is the environmental effect, $G_{i}$ is the genotypic effect, $G E_{h i}$ is the genotype $\times$ environment effect, $B_{j(h)}$ is the block effect, and $e_{h i j}$ is the random error. Biplots of GGE was composed from the general mean and IPCA score. STABILITYSOFT was also used to estimate combined ANOVA, GGE, and to form their biplots [18].

\section{Results and Discussion}

Combined ANOVA of yield for different locations and seasons is presented in Table 3. The analysis of variance revealed significant variations among the hybrids for yield. This is due to environment $(E)$, hybrid $(G)$, and hybrid$\times$ environment $(G E)$, with each contributing $48.72 \%$, $15.98 \%$, and $35.30 \%$, respectively. The effect of environmental factors indicated that the test environment conditions have a very significant difference. Table 4 provides significant differences between environments for maize hybrid yields $(p<0.01$ and $p<0.05)$. The differences in environmental conditions were also reported by several researchers including [8] on durum wheat, [19] on peanut, and [13] on sweet corn hybrid. The highly significant differences $(p<0.01$ and $p<0.05)$ between the maize hybrids tested are given in Table 5 . Based on Table 5, each genotype has different yield potentials. According to [20], the difference in yield potential of each tested genotype was caused by different genetic backgrounds. In this case, the genotypes used were hybrids resulting from cross-bred with different parental backgrounds.

The change response of hybrids when cultivated in multiple locations of diverse geographic islands, planting seasons (years), and climate types indicated the broad genetic potential of maize hybrid resulting in the possibility of determining suitable hybrids in two major maize production islands in Indonesia. Previous researchers stated the exis- 
TABLe 1: Agroclimatology of the location in Java and Sumatera islands.

\begin{tabular}{|c|c|c|c|c|}
\hline \multirow[b]{2}{*}{ No. } & \multirow[b]{2}{*}{ Location } & \multirow[b]{2}{*}{ Type of agroclimatology } & \multicolumn{2}{|c|}{ Environment code } \\
\hline & & & $\begin{array}{c}\text { Dry season, } \\
2013 \\
\end{array}$ & $\begin{array}{c}\text { Rainy } \\
\text { season, } 2014\end{array}$ \\
\hline 1 & $\begin{array}{l}\text { Karo, North Sumatera, } \\
\text { Sumatera Island }\end{array}$ & $\begin{array}{l}\text { BIII4. Climate type of moderate; yearly rain of } 1500-2500 \mathrm{~mm} \text {; number } \\
\text { of continuous dry month per year, }<3 \text {; number of continuous wet month, } \\
\qquad 3 \text {; potential of crop index, } 3\end{array}$ & $\mathrm{~L} 1$ & $\mathrm{~L} 2$ \\
\hline 2 & $\begin{array}{c}\text { Tanjung Bintang, Lampung, } \\
\text { Sumatera Island }\end{array}$ & $\begin{array}{l}\text { BIII3. Climate type of moderate; yearly rain of } 1500-2500 \mathrm{~mm} \text {; number } \\
\text { of continuous dry month per year, }<3 \text {; number of continuous wet month, } \\
\text { 3-4; potential of crop index, } 3\end{array}$ & L3 & \\
\hline 3 & $\begin{array}{l}\text { Gunung Sugih, Lampung, } \\
\text { Sumatera Island }\end{array}$ & $\begin{array}{l}\text { BIII2. Climate type of moderate; yearly rainy of } 1500-2500 \mathrm{~mm} \text {; number } \\
\text { of continuous dry month per year, }<3 \text {; number of continuous wet month, } \\
5-9 \text {; potential of crop index, } 3\end{array}$ & L4 & L5 \\
\hline 4 & $\begin{array}{c}\text { Jatinangor, Sumedang, West } \\
\text { Java }\end{array}$ & $\begin{array}{l}\text { AII2. Climate type of wet; yearly rain of }>2500 \mathrm{~mm} \text {; number of } \\
\text { continuous dry month per year, } 3-7 \text {; number of continuous wet month, } \\
\text { 5-9; potential of crop index, } 2\end{array}$ & L6 & L7 \\
\hline 5 & $\begin{array}{c}\text { Karanganom, Klaten, Central } \\
\text { Java, Java Island }\end{array}$ & $\begin{array}{l}\text { BII2 climate type of moderate; yearly rain of } 1500-2500 \mathrm{~mm} \text {; number of } \\
\text { continuous dry month per year, } 3-7 \text {; number of continuous wet month, } \\
\text { 5-9; potential of crop index, } 2\end{array}$ & L8 & L9 \\
\hline 6 & $\begin{array}{c}\text { Jogonalan, Klaten, Central } \\
\text { Java, Java Island }\end{array}$ & $\begin{array}{l}\text { BII3. Climate type of moderate; yearly rain of } 1500-2500 \mathrm{~mm} \text {; number of } \\
\text { continuous dry month per year, } 3-7 \text {; number of continuous wet month, } \\
\text { 3-4; potential of crop index, } 2\end{array}$ & L10 & L11 \\
\hline 7 & $\begin{array}{c}\text { Boyolali, Central Java, Java } \\
\text { Island }\end{array}$ & $\begin{array}{l}\text { AII2. Climate type of wet; yearly rain of }>2500 \mathrm{~mm} \text {; number of } \\
\text { continuous dry month per year, } 3-7 \text {; number of continuous wet month, } \\
\text { 5-9; potential of crop index, } 2\end{array}$ & L12 & L13 \\
\hline 8 & $\begin{array}{c}\text { Probolinggo, Eastern Java, } \\
\text { Java Island }\end{array}$ & $\begin{array}{l}\text { CI3. Climate type of dry; yearly rain of }<1500 \mathrm{~mm} \text {; number of continues } \\
\text { dry month }>7 \text {; number of continuous wet month, 3-4; potential of crop } \\
\text { index, } 1\end{array}$ & L14 & L15 \\
\hline 9 & $\begin{array}{l}\text { Jember, Eastern Java, Java } \\
\text { Island }\end{array}$ & $\begin{array}{l}\text { CII3. Climate type of dry; yearly rain of }<1500 \mathrm{~mm} \text {; number of } \\
\text { continuous dry month per year, } 3-7 \text {; number of continuous wet month, } \\
\text { 3-4; potential of crop index,2 }\end{array}$ & L16 & L17 \\
\hline 10 & $\begin{array}{l}\text { Nganjuk, Eastern Java, Java } \\
\text { Island }\end{array}$ & $\begin{array}{l}\text { BII3. Climate type of moderate; yearly rain of } 1500-2500 \mathrm{~mm} \text {; number of } \\
\text { continuous dry month per year, } 3-7 \text {; number of continuous wet month, } \\
\text { 3-4; potential of crop index, } 2\end{array}$ & L18 & L19 \\
\hline 11 & $\begin{array}{l}\text { Kediri, Eastern Java, Java } \\
\text { Island }\end{array}$ & $\begin{array}{l}\text { BII } 2 \text { climate type of moderate; yearly rain of } 1500-2500 \mathrm{~mm} \text {; number of } \\
\text { continuous dry month per year, } 3-7 \text {; number of continuous wet month, } \\
\text { 5-9; potential of crop index, } 2\end{array}$ & L20 & L21 \\
\hline
\end{tabular}

* Ministry of Agriculture Republic of Indonesia [1].

TABLe 2: The maize hybrids materials and their pedigree.

\begin{tabular}{|c|c|c|c|c|c|c|}
\hline \multirow{2}{*}{ No. } & \multirow{2}{*}{ Code } & \multirow{2}{*}{ Hybrid } & \multicolumn{3}{|c|}{ Parental line } & \multirow{2}{*}{ Pedigree } \\
\hline & & & Fema & & Male & \\
\hline 1 & G1 & $\mathrm{Cx}$ & & & & Hybrid commercial of Cargill \\
\hline 2 & $\mathrm{G} 2$ & Pxy & & & & Hybrid commercial of Pioneer \\
\hline 3 & G3 & NKxx & & & & Hybrid commercial of Monsanto \\
\hline 4 & G4 & Bisi $\mathrm{x}$ & & & & Hybrid commercial of Bisi \\
\hline 5 & G5 & PA & 1011 & $\times$ & 1016 & Female is a downy mildew-resistant line; male is a high-nutrition line \\
\hline 6 & G6 & $\mathrm{PB}$ & 1014 & $\times$ & 1018 & Female is a downy mildew-resistant line and male is a high-protein line \\
\hline 7 & G7 & $\mathrm{PC}$ & 1019 & $\times$ & 1020 & Both parents are high-nutrition lines \\
\hline 8 & G8 & $\mathrm{PE}$ & 1007 & $x$ & 1008 & Female is a high-yield line, and male is a high-nutrition line \\
\hline 9 & G9 & $\mathrm{PF}$ & 1006 & $\times$ & 1007 & Female is a high-nutrition line, and male is a high-yield line \\
\hline 10 & G10 & PG & 1008 & $\times$ & 1009 & Female is a high-nutrition line; male is a downy mildew-resistant line \\
\hline 11 & G11 & $\mathrm{PH}$ & 1002 & $\times$ & 1003 & Female is a high-nutrition and downy mildew-resistant line; male is a high-yield line \\
\hline
\end{tabular}

tence of important yield variations among hybrids tested for different conditions $[13,21,22]$. Significant effects of environment explained that every location in Java and Sumatera were unique due to their different agroclimate.
Significant interaction of hybrid $\times$ environment results revealed the presence of an interaction and variation in the position of the hybrids across various locations and seasons. The response of the hybrids is indicated by changed levels of 
TABLE 3: Combined ANOVA and statistics parameters for yield of maize hybrids under different environment in the western region of Indonesia.

\begin{tabular}{|c|c|c|c|c|c|c|}
\hline Source & df & SS & MS & $\mathrm{F}$ & F_prob & SS (\%) \\
\hline Genotypes (G) & 10 & 294.5 & 29.45 & $103.12^{*}$ & 0.00000 & 15.98 \\
\hline Environments (E) & 20 & 897.8 & 44.89 & $182.13^{*}$ & 0.00000 & 48.72 \\
\hline Block/E & 42 & 10.4 & 0.25 & 0.86 & 0.71471 & \\
\hline Interactions (GEIs) & 200 & 650.4 & 3.25 & $11.39^{* *}$ & 0.00000 & 35.30 \\
\hline Error & 420 & 120.0 & 0.29 & & & \\
\hline Minimum $\left(\right.$ t.ha $\left.^{-1}\right)$ & 2.99 & & & & & \\
\hline Maximum (t.ha $\left.{ }^{-1}\right)$ & 13.45 & & & & & \\
\hline Mean $\left(\right.$ t.ha $\left.^{-1}\right)$ & 8.76 & & & & & \\
\hline CV (\%) & 6.15 & & & & & \\
\hline
\end{tabular}

*Significant at the level of 5\%; ns, nonsignificant at the level of 5\%; MS, mean square; df, degree of freedom; Std. Dev, standard deviation; CV, coefficient of variance.

TABLE 4: Combined analysis of variance for grain yield data of twenty-one environment

\begin{tabular}{|c|c|c|c|}
\hline Environments & Range (t.ha ${ }^{-1}$ ) & \multicolumn{2}{|c|}{ Mean \pm Std. Dev } \\
\hline$L 1$ & $6.00-10.46$ & $8.03 \pm 1.33$ & fghi \\
\hline$L 2$ & $6.70-11.65$ & $9.68 \pm 1.13$ & $\mathrm{~cd}$ \\
\hline$L 3$ & $2.99-12.48$ & $8.13 \pm 2.57$ & efghi \\
\hline$L 4$ & $7.32-12.33$ & $9.90 \pm 1.49$ & bc \\
\hline$L 5$ & $5.64-9.76$ & $7.85 \pm 0.95$ & ghi \\
\hline$L 6$ & 7.529 .94 & $8.35 \pm 0.53$ & efghi \\
\hline$L 7$ & $8.55-13.04$ & $10.70 \pm 1.27$ & $\mathrm{~b}$ \\
\hline$L 8$ & $5.50-9.66$ & $7.53 \pm 1.16$ & hi \\
\hline$L 9$ & $7.55-13.18$ & $9.52 \pm 1.18$ & $\mathrm{~cd}$ \\
\hline$L 10$ & $5.94-11.16$ & $8.93 \pm 0.99$ & cdef \\
\hline$L 11$ & $6.64-11.33$ & $8.40 \pm 1.12$ & efgh \\
\hline$L 12$ & $6.80-11.84$ & $9.11 \pm 1.35$ & cde \\
\hline$L 13$ & $5.95-10.39$ & $7.48 \pm 1.03$ & hi \\
\hline$L 14$ & $5.08-9.79$ & $7.85 \pm 1.40$ & ghi \\
\hline$L 15$ & $6.15-10.91$ & $7.78 \pm 1.11$ & hi \\
\hline$L 16$ & $8.15-11.93$ & $9.80 \pm 0.94$ & bcd \\
\hline$L 17$ & $5.57-9.52$ & $7.33 \pm 0.94$ & $\mathrm{i}$ \\
\hline$L 18$ & $6.33-9.29$ & $7.57 \pm 0.91$ & hi \\
\hline$L 19$ & $10.05-13.41$ & $11.68 \pm 0.81$ & $\mathrm{a}$ \\
\hline$L 20$ & $7.60-13.45$ & $9.47 \pm 1.54$ & $\mathrm{~cd}$ \\
\hline$L 21$ & $6.98-11.55$ & $8.85 \pm 1.09$ & defg \\
\hline Mean & & 8.76 & \\
\hline LSD & & 0.88 & \\
\hline$F$ & & $* *$ & \\
\hline CV (\%) & & 11.89 & \\
\hline
\end{tabular}

*significant at the level of 5\%; and different letters in table refer to difference between environments.

yield decrease that could be projected under multiple locations due to the interaction between maize and its agroclimate factors such as number of continuous dry month per year, number of continuous wet month per year, total volume of rain per year, and crop index per year (Table 1). The interaction between crop and environment changed actively in aspects of ecology, physiology, and agronomy of crop under evaluation in different locations. This interaction could limit progress in selecting suitable hybrids with superior performance in various locations. Therefore, an appropriate breeding scheme needs to be formulated to improve stable varieties in wide locations or specific adapted varieties. Similar results were also concluded in previous experiments on maize hybrids under various environments [23-25].
All hybrids in this study had different genetic background including high-yield, high-nutrition, and downy mildew-resistant lines. Some of hybrids had higher yields than commercial check hybrids. This is revealing the potential for developing superior high-yield hybrids over the existing commercial hybrid in Indonesia. The highyield hybrids cultivated under different cropping systems and across planting seasons included inbred lines 1002, $1003,1008,1009,1014,1018,1019$, and 1020 as parental lines. Some of these hybrids include $G 6, G 7, G 10$, and $G 11$ (Table 2). The use of parental lines selected concurrently in multiple environments shall provide the gain of generating high-yielding hybrids. The experiments also confirmed the chance of identifying hybrids that can cultivate well across locations and specific locations; two 
TABLE 5: Combined analysis of variance of grain yield data of 11 maize hybrids.

\begin{tabular}{|c|c|c|c|}
\hline Genotypes & Range (t.ha ${ }^{-1}$ ) & \multicolumn{2}{|c|}{ Mean \pm Std. Dev } \\
\hline$G 1$ & $6.64-12.50$ & $8.83 \pm 1.36$ & $\mathrm{~b}$ \\
\hline$G 2$ & $6.46-12.52$ & $8.87 \pm 1.33$ & $\mathrm{~b}$ \\
\hline G3 & $6.91-13.45$ & $10.26 \pm 1.54$ & $\mathrm{a}$ \\
\hline G4 & $3.88-12.16$ & $8.50 \pm 1.88$ & $\mathrm{bc}$ \\
\hline G5 & $6.90-13.04$ & $8.80 \pm 1.42$ & $\mathrm{~b}$ \\
\hline G6 & $5.49-12.48$ & $8.43 \pm 1.81$ & $\mathrm{bc}$ \\
\hline G7 & $2.99-12.17$ & $7.84 \pm 1.60$ & $\mathrm{~cd}$ \\
\hline$G 8$ & $6.59-12.31$ & $9.15 \pm 1.50$ & $\mathrm{~b}$ \\
\hline G9 & $6.51-12.81$ & $9.05 \pm 1.49$ & $\mathrm{~b}$ \\
\hline G10 & $5.95-13.41$ & $8.91 \pm 1.50$ & $\mathrm{~b}$ \\
\hline G11 & $4.38-11.09$ & $7.70 \pm 1.59$ & $\mathrm{~d}$ \\
\hline LSD & & 0.63 & \\
\hline$F$ & & $* *$ & \\
\hline CV (\%) & & 11.89 & \\
\hline
\end{tabular}

* significant at the level of $5 \%$ and different letter in table refer to difference between genotypes.

of five top-yielding hybrids exhibited superior performance under distinctive multiple locations.

The GGE biplots for yield of 12 hybrids are shown in Figure 1. The values of the first principal component (PC1) and the second PC2 were estimated to generate a GGE biplot graph. The biplot graph aided on finding the best-performing genotypes adapted at the specific location or stable genotype for multiple locations and even determines the most representative locations (megaenvironment) for a genotype [11, 21, 22]. Furthermore, Kendel et al. [26] explained that the biplot graph could be applied to interpret the relationships among varieties, characters, and groups of traits. Figure 1 shows a "which-won-where" polygon view of the biplot presenting locations and seasons in the western region of Indonesia. The vertex hybrids for every sector of the biplot showed the top yielding hybrid in the locations and seasons which dropped in that sector. G10, a maize hybrid developed by Padjadjaran University, was maize hybrid positioned near the base of the biplot; therefore, this hybrid was more stable than the vertex hybrids. The line which starts from the base of the biplot and disperses vertical to the edges of the polygon arranged the biplot into distinctive sectors. G6, a maize hybrid developed by Padjadjaran University, was the top yielding maize hybrid for locations $L 1$ and $L 2$ (Karo in North Sumatera with dry and rainy season as the climate type of BIII4), L3 (Tanjung Bintang in Lampung with dry season as the climate type of $B I I I 3$ ), and $L 6$ and $L 7$ (Jatinangor in Sumedang, West Java, with dry and rainy season as the climate type of $A \mathrm{II} 2$ ); whereas, G3, a commercial hybrid developed by Monsanto, was the winner maize hybrid for the following locations $L 4$ and $L 5$ (Gunung Sugih in Lampung with dry and rainy seasons as the climate type of BIII2), L8 and L9 (Karanganom in Klaten in Central Java with dry and rainy seasons as the climate type of BII2), L10 and L11 (Jogonalan in Klaten in Central Java with dry and rainy seasons as the climate type of BII3), L12 and L13 (Boyolali in Central Java with climate type of AII2), L14 and L15 (Probolinggo in Eastern Java with climate type of CI3), $L 16$ and $L 17$ (Jember in Eastern Java with climate type of CII3), L18 and L19 (Nganjuk in Eastern Java with climate type of BII3), and L20
(Kediri in Eastern Java with climate type of BII2). Thus, G7, a maize hybrid developed by Padjadjaran University, was the vertex maize hybrid for location 21 (Kediri in Eastern Java with climate type of $B I I 2)$; however, no environments fell in the sector with G4, a maize hybrid developed by Bisi Seed Company, and G11, a maize hybrid developed by Padjadjaran University, as vertex hybrid (Figure 1).

The GGE biplot "which-won-where" patterns classified the biplot into five different sectors (Figure 1). Yan and Tinker [22] explained that there are several high-yielded hybrids for those sectors if diverse test environment existed in these diverse sectors. Furthermore, [6] suggested the presence of crossover GEI and proposed grouping of the diverse test environments into megaenvironments. Across various geographic locations and diverse climate types in Java and Sumatera islands, the polygon view of the biplot classified two sectors as megaenvironment (Figure 1). The first megaenvironment sector included hybrid $G 6$ as vertex and hybrids G2, G5, G8, G9, and $G 10$ as the members and locations as Karo in North Sumatera, Sumatera island (climate type of BIII4), Tanjung Bintang, Lampung, Sumatera Island (climate type of BIII3), and Jatinangor, West Java, Java Island (climate type of AII2). Generally, these environments represented the climate type of moderate-wet up to wet-dry (Figure 1). The second megaenvironment sector included hybrid $G 3$ as vertex and hybrid $G 1$ as the hybrid member and locations as Gunung Sugih in Lampung, Sumatera island (climate type of BIII2), $L 8$ and $L 9$ (climate type of BII2), L10 and L11 (climate type of BII3), $L 12$ and L13 (climate type of AII2), L14 and L15 (climate type of CI3), L16 and L17 (climate type of CII3), L18 and $L 19$ (climate type of BII3), and L20 (BII2). Thus, this environment represented the moderate-wet up to dry-wet type of climate (Figure 1). Some researchers explain that data are critical in grouping environments into diverse megaenvironments for suggesting different hybrids for different megaenvironments [23-25, 27]. No environment fell in the sector where G4 and G11 were the vertex hybrids, demonstrating that these hybrids were the lowest yielding hybrid used for the present study. The results of this study specified a preliminary data on megaenvironment delimitation of the 


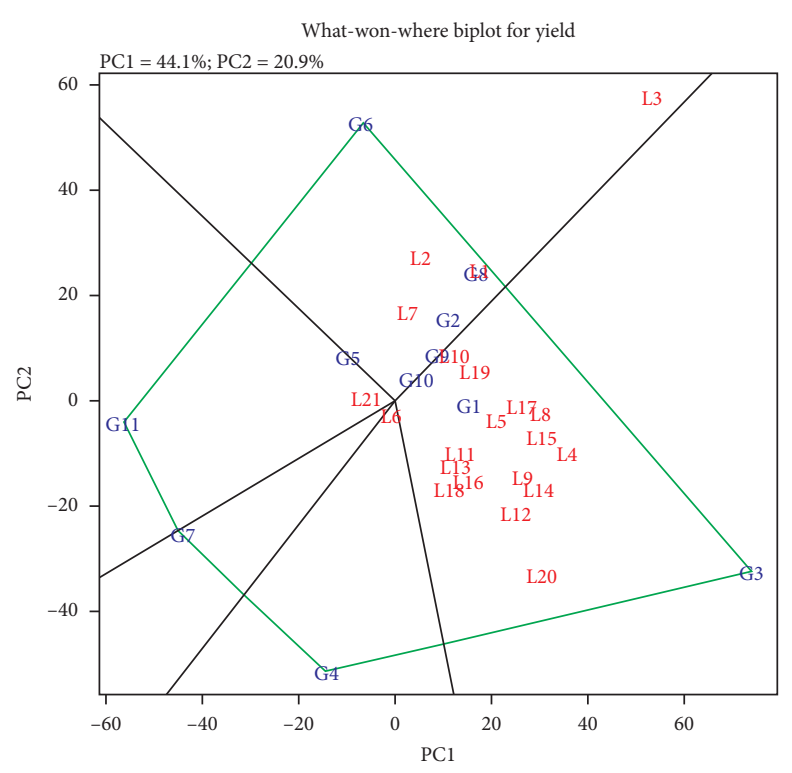

FIGURE 1: The "which-won-where" graph of the genotypic main effects plus genotype environment interaction (GGE) biplot for maize hybrids tested under multiple locations for rainy and dry seasons. The code of environments is given in Table 1. Code of genotypes is given in Table 2. PC, principal component.

test locations, and multilocations and season's evaluation are needed to confirm this finding.

The GGE biplot showing spot of hybrids relative to a model genotype for various locations and agroclimate is shown in Figure 2. In this study, the average environment coordinate (AEC) abscissa is the average environment axis (AEA). The AEC ordinate divides low average yield hybrids from those high average-yield hybrids. The small diamond is the average environment, and an ideal hybrid is described by the highest vector length and low $G \times E$ and is symbolized by the center of the bold diamond (Figure 2), suggesting the highest mean yield and stability. Yan and Kang [28] described the ideal genotype as the highest yielding and the most stable. In the present study, the most suitable hybrids which confined to the ideal genotype were classified under specific climate type suggesting specific adaptation (Figure 2). In this current study, high-yielding hybrids were G3, $G 8, G 2, G 9$, and $G 10$; whereas, the low yielding hybrids were $G 11, G 7, G 4, G 5$, and $G 6$. In addition, $G 9$ and $G 10$ were the most stable and high-yielding hybrids. In contrary to this result, G11 was the stable but low yielding hybrid. In addition, G3 was unstable but high-yielding hybrid for cultivating under particular agroclimate (Figure 2).

The vector view of the GGE biplot is shown in Figure 3. The graph revealed the connections of the environments and the biplot origin across the vectors. Most of locations have a positive association with ideal environment $\left(<90^{\circ}\right)$. The negative association $\left(>90^{\circ}\right)$, however, was detected between $L 1, L 2, L 3, L 6, L 7$ and $L 15, L 4, L 9, L 14, L 11, L 12, L 13, L 16$, $L 18, L 20$, and $L 21$. In addition, another negative association also occurred between location $L 10, L 19$ and $L 11, L 13, L 12$, $L 16, L 18, L 20$, and $L 21$. In the vector view of the GGE biplot graph, the length of the vector estimates the SD within each test environment. This vector's length is also a degree of ability from the environment to categorize the hybrids. Shorter environmental vectors explained that the specific environments were weakly connected with environments with longer vectors. The short-vector environments ( $L 5$ and L21) provided less evidence about the hybrids related to environments with longer vectors (L1-L20) (Figure 3). Kendal and Sener [8] explained that genotypes positioned around the center of the biplot contributed less to $G$ and/or $G E$, whereas genotypes with longer vectors contributed more to $G$ and/or $G E$.

Yan [29] explained the relationships of the angle between the vectors of two test environments as follows:

(i) An angle of less than $90^{\circ}$ revealed a connection of genotype performance between these environments

(ii) An exact angle of $90^{\circ}$ revealed orthogonality and weak association and

(iii) An angle of more than $90^{\circ}$ revealed a negative connection of genotype performance between these environments

As explained by [23], Oyekunle et al. [10], and [25], positive correlations revealed the connection of genotype performance among the environments, whereas negative or weak correlations demonstrate the strong influence of the GEI. Furthermore, [28] suggested that if strong negative correlations existed between test environments, specific environments are required to be handled separately for genotype evaluation to improve the gain of selection for high yield. Environments with strong positive correlations are considered laid off due to increase trial evaluation expenses. The vector view of the GGE biplot in Figure 3 describes that locations of $L 1, L 2, L 6, L 7, L 10$, and $L 19$ showed a strong negative correlation with other locations ( $L 15, L 4, L 9, L 14$, $L 11, L 12, L 13, L 16, L 18, L 20$, and $L 21)$, suggesting that these 


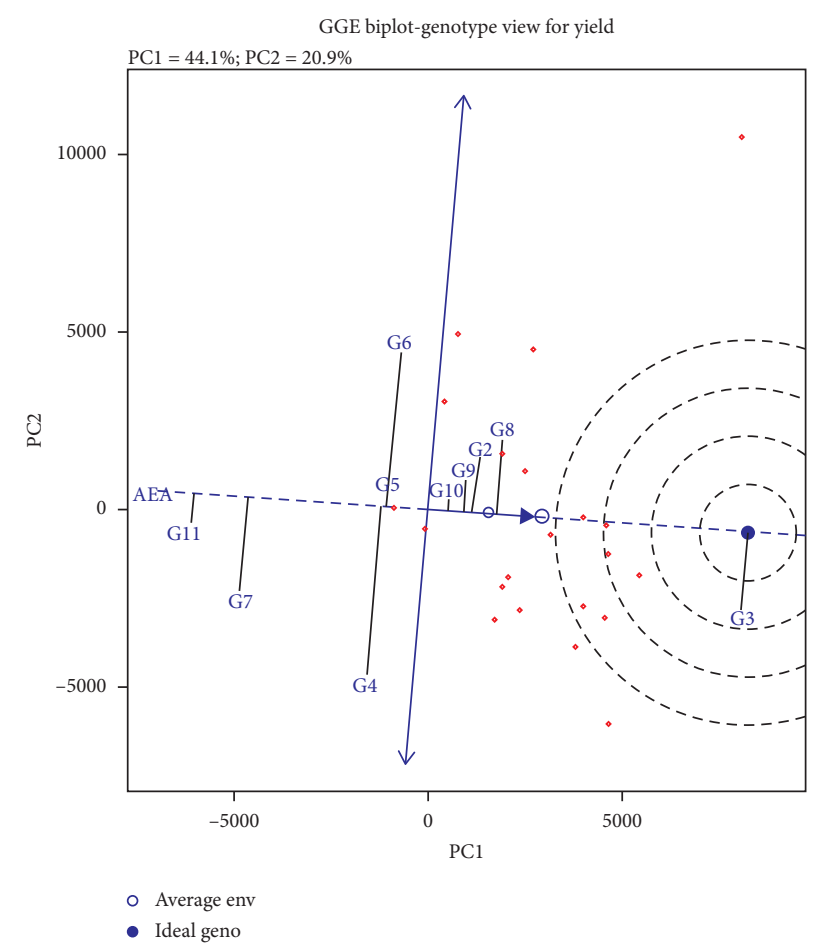

FIGURE 2: The GGE biplot viewing position of maize hybrids compared to an ideal genotype for the following cropping systems for rainy and dry seasons. The code of environments is given in Table 1. Code of genotypes is given in Table 2. PC, principal component.

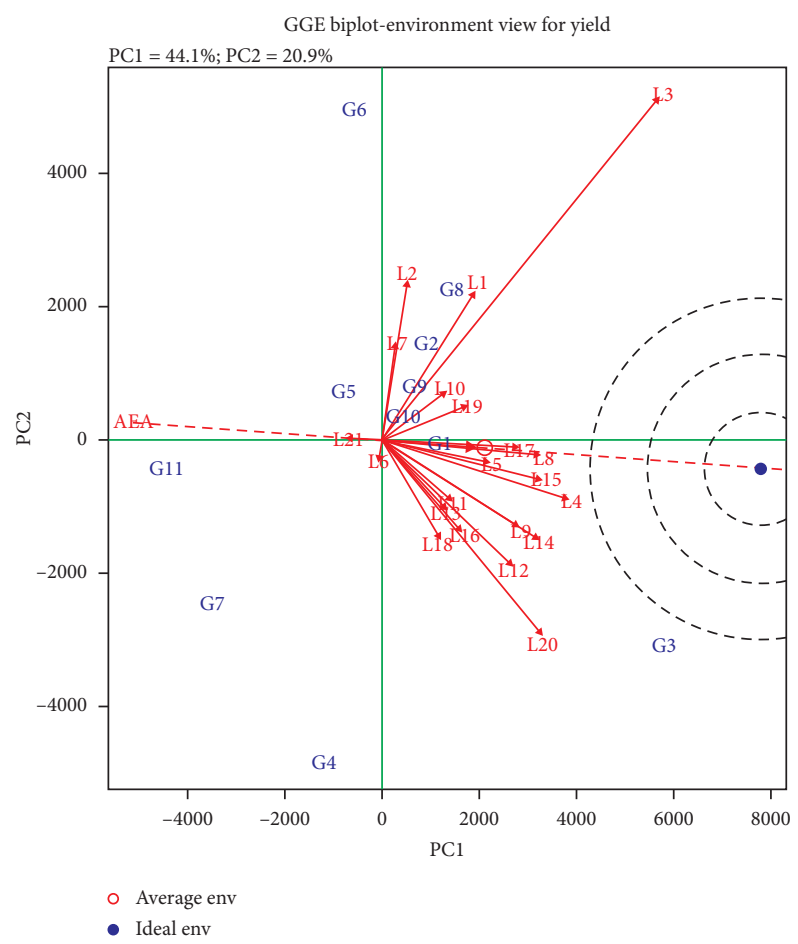

FIGURE 3: The vector view of GGE biplot showing the "discriminating power and representativeness" of the trial environments to assess maize hybrids under different cropping systems for rainy and dry seasons. The code of environments is given in Table 1 . Code of genotypes is given in Table 2. PC, principal component. 
locations were different. It is, therefore, selection for highgrain yield in Java and Sumatera islands should be conducted separately in these locations. In addition, Tiga Binanga in North Sumatera ( $L 1, L 2$; climate type of BIII4), Jatinangor in West Java ( $L 6, L 7$; climate type of AII2), Karanganom in Klaten, Central Java ( $L 7, L 8$; climate type of $B I I 2)$, and Jember (L17, L18; climate type of CII3) were representative locations for high-yielding maize hybrid selection in Sumatera and Java islands.

Yan et al. [6] described valuable environment for evaluating cultivars as environments with long vectors and slight angles with the AEC abscissa. In the present study, the AEC abscissa was equal to AEA; hence, $L 17$ and $L 8$ were classified as discriminant environments for the hybrids evaluated in the western region of Indonesia. Oyekunle et al. and Mebratu et al. $[10,25]$ mentioned that the test environments as "ideal environments" for selecting superior hybrids and identification of adaptive varieties for specific environment. Furthermore, $[10,12,25]$ explained that by testing discriminant conditions in the early stage that will reduce varieties improvement cost by cutting the number of varieties to be selected and reducing the number of locations/seasons.

\section{Conclusion}

The stable maize hybrids and adapted maize hybrids for the western region of Indonesia in Sumatera and Java islands can be determined in this study. Based on GGE biplots, the stable maize hybrids for the western region of Indonesia were maize hybrids $G 9$ and G10. G6 was the top yielding maize hybrid for megadiversity 1 covering locations Karo in North Sumatera, Tanjung Bintang in Lampung in Sumatera Island, and Jatinangor, Sumedang, West Java in Java island; whereas, G3 was the selected hybrid for the second megaenvironment covering Gunung Sugih in Lampung; Karanganom in Klaten, Jogonalan in Klaten, and Boyolali in Central Java; and Probolinggo, Jember, Nganjuk, and Kediri in Eastern Java. The $L 8$ and $L 17$ were the discriminant environment for evaluating hybrids in the western region of Indonesia. The high-yielding hybrids selected in this study should be broadly evaluated on-farm in order to disseminate for small holder farmers in Sumatera and Java islands.

\section{Data Availability}

The data used to support the findings of this study are included within the article.

\section{Conflicts of Interest}

The authors declare that they have no conflicts of interest.

\section{Acknowledgments}

The research was funded by the University of Padjadjaran (1427/UN6.3.1/LT/2020) for the Competency Research Grant and Academic Leadership Grant.

\section{References}

[1] Ministry of Agriculture Republic of Indonesia, Atlas Sumber Daya Agroklimat Indonesia, Ministry of Agriculture Republic of Indonesia, Jakarta, Indonesia, 2019, http://informasi-sdagroklimat.com/agroklimat/assets/pdf/20200204073316_ Narasi.pdf.

[2] X.-M. Fan, M. S. Kang, H. Chen, Y. Zhang, J. Tan, and C. Xu, "Yield stability of maize hybrids evaluated in multi-environment trials in Yunnan, China," Agronomy Journal, vol. 99, no. 1, pp. 220-228, 2007.

[3] M. S. Kang, "A rank-sum method for selecting high-yielding, stable corn genotypes," Cereal Research Communications, vol. 16, pp. 113-115, 1988.

[4] W. Yan, P. L. Cornelius, J. Crossa, and L. A. Hunt, "Two types of GGE biplots for analyzing multi-environment trial data," Crop Science, vol. 41, no. 3, pp. 656-663, 2001.

[5] W. Yan, L. A. Hunt, Q. Sheng, and Z. Szlavnics, "Cultivar evaluation and mega-environment investigation based on the GGE biplot," Crop Science, vol. 40, no. 3, pp. 597-605, 2000.

[6] W. Yan, M. S. Kang, B. Ma, S. Woods, and P. L. Cornelius, "GGE biplot vs. AMMI analysis of genotype-by-environment data," Crop Science, vol. 47, no. 2, pp. 643-653, 2007.

[7] R. O. Akinwale, M. A. B. Fakorede, B. Badu-Apraku, and A. Oluwaranti, "Assessing the usefulness of GGE biplot as a statistical tool for plant breeders and agronomists," Cereal Research Communications, vol. 42, no. 3, pp. 534-546, 2014.

[8] E. Kendal and O. Sener, "Examination of genotype $\times$ environment interactions by GGE biplot analysis in spring durum wheat," Indian Journal of Genetics and Plant Breeding (The), vol. 75, no. 3, pp. 341-348, 2015.

[9] K. Rahmatollah, M. Mohtasham, S. Naser, A. M. Ali, R. Barzo, and S. M. Faramarz, "GGE Biplot analysis of yield stability in multi-environment trials of lentil genotypes under rainfed condition," Notulae Science Biologicae, vol. 5, pp. 256-262, 2013.

[10] M. Oyekunle, A. Haruna, B. Badu-Apraku et al., "Assessment of early-maturing maize hybrids and testing sites using GGE biplot analysis," Crop Science, vol. 57, no. 6, pp. 2942-2950, 2017.

[11] M. Kaplan, K. Kokten, and M. Akcura, "Assessment of genotype $\times$ trait $\times$ environment interactions of silage maize genotypes through GGE biplot," Chilean Journal of Agricultural Research, vol. 77, no. 3, pp. 212-217, 2017.

[12] E. Gasura, P. S. Setimela, and C. M. Souta, "Evaluation of the performance of sorghum genotypes using GGE biplot," $\mathrm{Ca}$ nadian Journal of Plant Science, vol. 95, no. 6, pp. 1205-1214, 2015.

[13] D. Ruswandi, Y. Yuwariah, M. Ariyanti, M. Syafii, and A. Nuraini, "Stability and adaptability of yield among earliness sweet corn hybrids in West Java, Indonesia," International Journal of Agronomy, vol. 2020, Article ID 4341906, 9 pages, 2020.

[14] Y. A. Mustamu, K. Tjintokohadi, W. J. Grüneberg, A. Karuniawan, and D. Ruswandi, "Selection of superior genotype of sweet-potato in Indonesia based on stability and adaptability," Chilean Journal of Agricultural Research, vol. 78, no. 4, pp. 461-469, 2018.

[15] M. Munawar, G. Hammad, and M. Shahbaz, "Evaluation of maize (Zea mays L.) hybrids under different environment by GGE biplot analysis," American-eurasian Journal of Agriculture \& Environment Science, vol. 13, pp. 1252-1257, 2013. 
[16] K. A. Gomez and A. A. Gomez, Prosedur Statistik Untuk Penelitian Pertanian. Edisi Kedua, UI-Press, Champaign, IL, USA, 1995.

[17] H. G. Gauch, "Statistical analysis of yield trials by AMMI and GGE,” Crop Science, vol. 46, no. 4, pp. 1488-1500, 2006.

[18] A. Pour-Aboughadareh, M. Yousefian, H. Moradkhani, P. Poczai, and K. H. M. Siddique, "Stability Soft: a new online program to calculate parametric and non-parametric stability statistics for crop traits," Applications in Plant Sciences, vol. 7, no. 1, Article ID e1211, 2019.

[19] B. C. Ajay, S. K. Bera, A. L. Singh, N. Kumar, K. Gangadhar, and P. Kona, "Evaluation of genotype $\mathrm{x}$ environment interaction and yield stability analysis in peanut under phosphorus stress condition using stability parameters of AMMI model," Agricultural Research, vol. 9, no. 1, pp. 1-10, 2020.

[20] A. Karuniawan, H. Maulana, D. Ustari et al., "Yield stability analysis of orange-fleshed sweet potato in Indonesia using AMMI and GGE biplot,” Heliyon, vol. 7, pp. 1-10, 2021.

[21] F. A. Tonk, E. lker, and M. Tosun, "Evaluation of genotype $\mathrm{x}$ environment interactions in maize hybrids using GGE biplot analysis," Crop Breeding and Applied Biotechnology, vol. 11, pp. 1-9, 2011.

[22] W. Yan and N. A. Tinker, "Biplot analysis of multi-environment trial data: principles and applications," Canadian Journal of Plant Science, vol. 86, no. 3, pp. 623-645, 2006.

[23] D. Abakemal, H. Shimelis, and J. Derera, "Genotype-by-environment interaction and yield stability of quality protein maize hybrids developed from tropical-highland adapted inbred lines," Euphytica, vol. 209, no. 3, pp. 757-769, 2016.

[24] B. Badu-Apraku, C. G. Yallou, K. Obeng-Antwi et al., "Yield gains in extra-early maize cultivars of three breeding eras under multiple environments," Agronomy Journal, vol. 109, no. 2, pp. 418-431, 2017.

[25] A. Mebratu, D. Wegary, W. Mohammed, A. Teklewold, and A. Tarekegne, "Genotype environment interaction of quality protein maize hybrids under contrasting management conditions in eastern and southern africa," Crop Science, vol. 59, pp. 1576-1589, 2018.

[26] E. Kendal, M. S. Sayar, S. Tekdal, H. Aktas, and M. Karaman, "Assessment of the impact of ecological factors on yield and quality parameters in Triticale using GGE biplot and AMMY analysis," Pakistan Journal of Botany, vol. 48, no. 5, pp. 1903-1913, 2016

[27] B. Badu-Apraku, M. Oyekunle, K. Obeng-Antwi et al., "Performance of extra-early maize cultivars based on GGE biplot and AMMI analysis," The Journal of Agricultural Science, vol. 150, no. 4, pp. 473-483, 2012.

[28] W. Yan and M. S. Kang, GGE Biplot Analysis a Graphical Tool for Breeders, Geneticists, and Agronomists, CRC Press, Boca Raton, FL, USA, 2003.

[29] W. Yan, "Singular-value partitioning in biplot analysis of multienvironment trial data," Agronomy Journal, vol. 94, no. 5, pp. 990-996, 2002. 